\title{
Semi-peripheral financialisation: the case of Portugal
}

\author{
João Rodrigues ${ }^{a}$, Ana C. Santos ${ }^{b}$ and Nuno Teles ${ }^{b}$
}

${ }^{a}$ Faculty of Economics and Centre for Social Studies, University of Coimbra, Portugal; ${ }^{b}$ Centre for Social Studies, University of Coimbra, Portugal

\begin{abstract}
This paper presents the main features of the financialisation of the Portuguese economy and society by focusing on the relation between the Portuguese financial sector and both external and domestic economic agents. It underlines the role played by the insertion of domestic finance into international financial markets in the financialisation of the country. Based on the Portuguese case, it elaborates on the theoretical understanding of the context-specific nature of semi-peripheral financialisation aimed as a contribution to an emerging body of literature addressing this phase of capitalism.
\end{abstract}

\section{KEYWORDS}

semi-periphery; financialisation; capitalism; European integration; Euro; Portugal.

\section{FINANCIALISATION: A CONTEXT-SPECIFIC PROCESS}

Financialisation, broadly understood as the rise of the economic and political power of financial actors, motives and markets in the economy and society, has emerged as one of the most studied subjects within political economy over the past 10 years (e.g. Epstein, 2005; Fine, 2010; Krippner, 2005; Lapavitsas, 2009; Van Treeck, 2009). Critical international political economy (IPE), in particular, has contributed to this literature, challenging the notion of a homogeneous erosion of state power caused by global financial markets (Helleiner, 1994; Konings, 2007). It argues instead that changes in the world economy stem from an institutional reconfiguration of international power carried out by dominant States through their capacity to devise new rules that have different national 
and regional impacts. The notion of structural power, i.e. 'power that is exercised indirectly and operates through shaping preferences and influencing the conditions under which other actors make decisions' (Konings, 2007: 37), is here decisive to account for the way in which the United States acquired a new power position in the international arena through its ability to maintain the dollar as world money after the demise of the Bretton Woods system. This was due, among other things, to the capacity of the US government to promote, and benefit from, the rise of financial markets.

However, studies on financialisation have mainly focused on the most mature capitalist countries of the centre, taking the USA and the UK as archetypes of financialised economies and societies. This has also been the case of IPE, with few exceptions (e.g. Abdelal, 2006). Financialisation in critical IPE has also focused on the Anglo-American world. The role of European integration, in general, and of the Euro, in particular, in promoting financialisation, with asymmetric contents and impacts, and its unfulfilled potential to become a hegemonic currency have not deserved sufficient attention (Fields and Vernengo, 2013).

But increased interest in the varied nature of the rise of finance in other geographical contexts is now emerging (e.g. Becker et al., 2010; Lapavitsas and Powell, 2013). This paper aims to contribute to this recent literature by focusing on the Portuguese case, both in its commonalities with other processes of financialisation and, most importantly, in its specificities. By drawing attention to semi-peripheral realities and the way these are moulded by the European Monetary Union it endeavours to enrich critical IPE.

We argue that the financialisation of the Portuguese economy and society was a rapid, but effective, process of socioeconomic transformation. Within the time-span of a mere decade, between the mid-1980s and the mid-1990s, the Portuguese financial system evolved from a Statecontrolled and 'repressed' financial regime to become a fully integrated and liberalised one, supported by firm insertion in international circuits of finance. Despite the speed of these transformations, the transition was smoothly produced without the financial instability that frequently accompanies such processes (Kaminsky and Reinhart, 1999). The Portuguese case is even more remarkable when considering the scope and depth of these transformations. The recent evolution of the (non-financial) private sector testifies to the magnitude of these changes, progressing from a very timid engagement with finance to skyrocketing levels of private indebtedness, the main culprit for turning Portugal into one of the highest externally indebted countries in the world. While some of these trends are partially shared with other semi-peripheral European countries that have common structural elements, namely Greece and Spain, the combination of high external debt and economic stagnation, 
starting at the beginning of the millennium, sets it apart from these countries.

This paper starts, in Section 2, by setting out our theoretical starting point within political economy and advancing our understanding of semi-peripheral financialisation. It then moves on to the analysis of the recent evolution of the Portuguese financial sector and of its relation with other economic agents. Section 3 presents the main institutional transformations of the financial sector, namely through the national transposition of progressively market-creating and market-conforming EU regulation in the financial sphere. Section 4 examines how Portuguese finance engaged with international markets, particularly money markets. Section 5 analyses the relation of finance with non-financial firms, which is pivotal to understanding the dynamics of stagnation and crisis of the Portuguese economy since 2000. Section 6 addresses the relation of finance and households, which have also become increasingly integrated with financial markets through their borrowing and saving decisions. Finally, and based on the main features of the financialisation of the Portuguese economy and society, Section 7 elaborates on the theoretical understanding of the context-specific nature of semi-peripheral financialisation aimed as a contribution to an emerging body of literature addressing this phase of capitalism.

\section{THEORISING SEMI-PERIPHERAL FINANCIALISATIONS}

At the most general level, financialisation has been defined as a set of historical and institutional processes whereby specific financial actors, motives and markets have gained an increased weight in, and exerted a growing influence upon, the rest of the economy and society (Epstein, 2005). These processes, most visible in the Anglo-Saxon world, are deemed to encompass a wide range of socioeconomic phenomena: privatisation, deregulation and market-led reregulation of financial activities, allowing the penetration of finance into ever more areas of economic and social life; the expansion and proliferation of different types of financial asset; the primacy of financial interests and imperatives in capital accumulation, increasing income inequality arising out of the weight of financial rewards; consumer-led booms based on credit, and so forth (Fine, 2010).

The term financialisation, which started to be used by Marxist political economists in the 1990s, has gained increasing currency among other heterodox economists - of post-Keynesian and institutionalist, mainly regulationist, persuasions - and other social scientists interested in realworld transformations of the economy. At risk of oversimplifying what has been a vibrant discussion about complex phenomena, we distinguish 
two main positions in the literature focusing upon the causes and effects of the rise of finance to a hegemonic position within capitalism since the 1970s. First, a Marxist tradition takes as the main factor leading to the rise of finance the escape of capital from a stagnated or depressed productive sphere, riddled with problems of profitability, to the more rewarding financial sector (Arrighi, 1994; Foster, 2007; Sweezy, 1994). Second, from a post-Keynesian and an institutionalist tradition, the rise of finance has been interpreted as the product of dominant neoliberal economic policies and institutional transformations - ranging from the privatisation of the banking sector, the opening up of capital-accounts throughout the world economy to disinflationary policies, which have caused a general decline in capital accumulation in a context of growing economic inequality, wage-stagnation and financial instability (Boyer, 2000; Krippner, 2005; Van Treeck, 2009). The literature has since matured while continuing to focus on the most financialised Anglo-Saxon economies. But, as Fine (2011: 6) underlines, rather than an 'analytical tool from which outcomes can be readily and simply read off'; financialisation must be first and foremost understood as a 'process that interacts with others in the context of specific economies', underlining the importance of taking into account specific, historically-given conditions and particular geographical contexts.

Converging with Fine's concern, and located within the Marxist tradition, Lapavitsas (2013: 39) states that 'the aim of theoretical analysis cannot be to produce a generally valid abstract model of financialization but rather to specify its underlying tendencies and to ascertain the particular form and content it acquires in different contexts'. From this it follows that 'period analysis must occupy a middle ground, departing from theoretical concerns while systematically integrating historical phenomena in a theoretically informed way' (Lapavitsas, 2013: 169). With these concerns in mind, Lapavitsas has developed a theoretical framework that incorporates the historically and institution-specific nature of financialisation processes and the spatially varied interactions between finance and the rest of the economy. In this view, States, endowed with different degrees of power and capacity for intervention, are of fundamental importance in accounting for the deliberate political and institutional elements that have shaped the rise of finance in a necessarily hierarchical world economy. This does not exclude the influence of more spontaneous processes, such as those stemming from the relations among agents occupying different positions in the spheres of production and circulation, within capital accumulation. Thus, the rising political and economic power of finance results from profound changes in the social relations of financial markets, banks, non-financial firms and households, where the State is a most relevant actor. This is taken as relevant to critical IPE since power relations in the world economy increasingly depend on a set of 
varied, mostly credit based, social relations between finance and other economic agents.

Based on the experience of mature capitalist economies, Lapavitsas identifies several tendencies shaping the financialisation of capitalism: the rise of investment banking; the rise of finance-to-finance lending; and, most importantly, the new centrality of bank lending to households. He then highlights the importance of these tendencies to compensate for the retreat of non-financial firms from loan markets due to an increasing reliance on capital markets for investment and funding. This is deemed to signal the changing nature of banks since 'at the root of financialization lies loanable, [i.e. hoarded funds collected either from the circuits of production and/or personal income] - not fictitious [i.e. net present value of securitised assets], capital' (Lapavitsas, 2013: 29).

For Lapavitsas, the concept of loanable capital is not circumscribed to a 'monied' capitalist class that lends interest-bearing capital (IBC) to 'functioning' capitalists who borrow it and invest in the productive sphere (see also Lapavitsas, 1997). Nor are interest payments conceived solely as the material basis of a specific group of capitalists, such as the Keynesian rentier class that profits from the mere accumulation of financial assets. Lapavitsas proposes instead a broader notion of loanable capital, which also mobilises idle money from workers and other social groups, and expands it to lending to non-productive activities, such as household consumption. The notion of 'financial expropriation' is then advanced to account for exploitative aspects deriving from new power relations emerging between capital and labour, where profits are increasingly generated out of wage income through payments of interest to financial institutions (Lapavitsas, 2009).

This approach differs from other Marxist approaches to financialisation, most notably that developed by Fine $(2010,2013)$, which restrains the use of IBC to the realm of production and capital accumulation and refuses the concept of financial expropriation. In fact, Fine defines financialisation as a 'peculiar modern form of incorporating a variety of credit relations into the orbit of fictitious capital' (2013: 56), with the latter conceived of as 'the independent circulation of IBC in paper form' (2013: 50). In this view, then, credit outside the realm of production also becomes forms of interest-bearing capital when these credit relations are converted into securitised assets and sold. The implication of this is that 'those buying the fictitious capital are advancing money capital in the expectation of a surplus even though the origins of this surplus do not lie in such an exchange' (2013: 55).

While finding the notion of financial expropriation debatable, especially so in the Portuguese case (see Section 6), and acknowledging the growing relevance of the extensive and intensive expansion of interestbearing capital in paper form (i.e. fictitious capital), Lapavitsas's broader 
notion of loanable capital is more adequate to account for semi-peripheral forms of financialisation. As we shall see, in Southern European countries, where capital markets are less mature, national and international bank loans have been the main driving forces behind financialisation, increasingly involving non-financial firms and households in finance (particularly as debtors, but also as asset holders).

The prevalence of loanable capital, whose scale and forms are shaped by the political and institutional conditions of the spaces where it is rooted, is a critical source of variation in financialisation. In order to understand why 'neither the content nor the form of financialization is fixed' across countries (Lapavitsas and Powell, 2013: 360), it is necessary to enlarge the scope of the analysis beyond countries of the centre of the capitalist world economy. To this end, Lapavitsas (2013) put forward the concept of 'subordinated financialization', according to which peripheral countries are compelled to join an increasingly financialised world economy, through formal and informal pressures, mainly by opening themselves up to financial flows and by accumulating reserves of quasi-world money (mostly dollars) needed to ensure their participation in international trade and financial transactions (Lapavitsas, 2013; Painceira, 2009). ${ }^{1}$ While illuminating important aspects of financialisation outside the core, namely the way the periphery tends to be crucially shaped from the outside by the interests of international finance located in the major advanced capitalist countries, and from the national and international institutions under their influence, the notion of subordinated financialisation has less to say about the equally crucial relations taking place outside the core between financial institutions, non-financial firms and the new major recipients of credit, households. The lack of attention to domestic interactions between financial and non-financial agents is shared by other accounts of financialisation processes outside the core (Hardie, 2011; Zhang, 2009).

Lapavitsas's framework can be usefully complemented by Becker et al.'s (2010) adaptation of the regulationist approach to grasp the heterogeneous nature of the 'regimes of accumulation' across the peripheries and semiperipheries of the world economy. Through a tripartite typology of regimes of accumulation - productive versus financialised, intensive versus extensive and introverted versus extraverted - they analyse the commonalties and specificities of the trajectories of four different countries Brazil, Chile, Serbia and Slovakia. ${ }^{2}$ Resulting from external impositions, although necessarily linked to the goals and interests of fractions of domestic capital, financialisation outside the core tends to require high interest rates in order to attract international capital flows, producing bouts of speculation and leading to overvalued exchange rates and to the erosion of productive capacities. This means that low interest rates and more substantial inflows of capital can only be, and temporarily so, 
achieved through '(semi)dollarized or euroized models', i.e. under regimes of fixed exchange rates, with nationals having incentives to become highly indebted in foreign currency (Becker et al., 2010: 230).

Becker's framework is sharp and flexible enough to account for the Portuguese case. With a colonial past, Portugal is a semi-peripheral country within the world economy, which combines characteristics of developed and developing countries, being marked by late industrialisation and lasting backward economic development relative to the core Northern and Central European countries (Santos, 1985). With decolonisation occurring in the 1970s, the country rapidly geared towards integration in the then European Economic Community (EEC), formalised in 1986 (Pinto and Teixeira, 2002). New foreign direct investment, benefiting from structural EU funds and lured by low wages, fuelled economic growth during the first years of integration. Despite some localised bouts of industrial modernisation and overall catching-up, the Portuguese economy continued to rely on traditional labour-intensive industrial sectors such as textiles (Rodrigues and Reis, 2012).

Portugal's laggard position in the European context reinforced the role of the European Union in driving the financialisation of the Portuguese economy and society. The participation in the Eurozone, in particular, brought unprecedentedly advantageous financial conditions, such as an almost unlimited access to hard currency and loanable capital at low interest rates, which are often unavailable to countries with similar levels of development. But this process ultimately had to face the structural contradictions of the country. The absence of an autonomous monetary policy in the face of growing international competition exacerbated the structural economic weaknesses of the Portuguese economy, manifested in a persistent and growing current account deficit, fuelling an equally growing external debt.

The notion of semi-peripheral financialisation is particularly useful to account for the convergences and divergences between the Portuguese economy and financialisation processes occurring both in the core and on the periphery. The term semi-periphery is here adopted in a double sense. First, it accounts for the intermediate position of the Portuguese economy in the world economy, i.e. as an industrialised country that is increasingly unable to compete with countries with which it is most closely integrated, favouring the growth of the more protected nontradeable sector. Second, it refers to the institutional features of its financial system, which shares characteristics of both core and peripheral countries, being mostly shaped by the process of European integration and by the predominance of loanable capital. ${ }^{3}$

As will be argued below, the notion of semi-periphery is also most helpful to underline the 'uneven and combined' character of capitalism (Ashman, 2009), allowing for better accounting of the national and 
sectoral variation of financialisation processes. Different financialised configurations are not only shaped by extant interests and power relations, among domestic and international agents. They are also influenced by underlying social, political, economic, geographic and historical factors, avoiding simplistic relations of dependence between the semiperiphery and the core. Particular attention needs to be paid to distinctive and commodity-specific systems of provision and how they interact with finance (Bayliss et al., 2013). In the case of household engagement with finance, for example, particular attention needs to be given to the Portuguese housing provision system that is mostly directly associated with household borrowing as access to housing has been increasingly associated with mortgage markets.

The concept of semi-peripheral financialisation put forward thus points to differences in form and content relative to financialisation processes in core countries. It underlines the more predominant and critical role of bank loanable capital in shaping recent and profound changes in semi-peripheral countries. It emphasises the role of international finance located in advanced capitalist countries. And it incorporates domestic relations between financial institutions, non-financial firms and households, which are crucial to account for variation within semi-peripheral countries.

\section{FINANCIALISATION IN PORTUGAL: THE INTERNATIONAL CONTEXT}

This section briefly summarises the main hallmarks of the recent history of Portuguese finance, which was one of the most 'repressed' financial systems in Western Europe in the early 1980s, becoming rapidly, but effectively, a highly liberalised one.

The democratisation of the country in 1974-75 led to the nationalisation of relevant private economic groups that had dominated the country's political economy during Salazar's dictatorship, including all major banks. In this highly interventionist period, interest rates were set administratively, and credit was mostly directed towards the needs of the State and of the associated public enterprises in strategic sectors; there were also strict controls on capital flows, and the exchange rate was defined using a sliding scale pegged to a basket of foreign currencies from 1978 onwards. This configuration, locked-in by a socialist leaning Constitution declaring nationalisations as irreversible conquests of the working-class', was antithetical to the wider neoliberal international trends of the early eighties with which Portugal eventually aligned, albeit, as typical in a semi-periphery, with a time lag.

The combination of two IMF interventions (in 1979 and in 1983-85) and the preparation for accession to the EEC set a favourable context for 
what has been uncritically labelled as the 'modernisation' of the Portuguese financial system from the mid-eighties onwards (Pinto, 1996; Nunes, 2011). Indeed, the liberalisation of the banks began in 1984 when new private banks were allowed. The first Portuguese private bank, the Banco Comercial Português, was founded, soon followed by the entry of new foreign banks, such as the Spanish bank Santander (Mendes and Rebelo, 2003). In 1989, following a revision of the Constitution, allowing the reversing of nationalisations, the move towards privatising State banks began (Banco Totta, Banco Espírito Santo, Banco Português do Atlântico), with the exception of the Caixa Geral de Depósitos, which remains state-owned to the present day. In just seven years, between 1990 and 1996, State banks became just one fourth of the market share, falling from $74 \%$ to approximately $24 \%$, while the market share of foreign banks tripled from 3\% in 1991 to 9\% in 2000, maintaining more or less the same position since then (Antão et al., 2009). However, as a result of further mergers and acquisitions, activity in the sector was eventually concentrated around five major banks: the Caixa Geral de Depósitos, Banco Comercial Português, Banco Santander, Banco Espírito Santo and Banco Português de Investimento. ${ }^{4}$

The privatisation and liberalisation of the financial sector, which put an end to credit limits and administrative interest rates, was the first set of factors contributing to the increase in bank loans in the 1990s. A second set of factors is linked to the release of (poorly remunerated) compulsory reserves deposited in the Bank of Portugal, which were subsequently transformed into public debt negotiable at market prices. The rate for compulsory reserves in the Bank of Portugal fell from 17\% in 1989 to 2\% in 1994, in line with European practice. There was, therefore, a quantity and price effect associated with the growth of credit in Portugal, i.e. greater available liquidity at lower prices, which favoured the expansion of credit.

The expansion of credit cannot therefore be separated from the monetary policy of the Portuguese State. The State's role in the necessary task of politically constructing financial markets also involved the gradual rise of securitised public debt, traded on secondary markets and open to foreign investors. Moreover, from 1990, the Bank of Portugal started to restrict its treasury loans as part of the process of breaking national links between the Treasury and the Central Bank, supposedly as a means of assuring Bank of Portugal independence. As a result, the State became totally dependent on the financial markets for financing its deficits.

Legislation regulating the financial system - under Decree-Law no. 298/92 - was the last milestone in the deregulation of the financial sector, transposing the 1989 European Directive into Portuguese law. Within the framework of the European single market for goods and services, this law aimed to liberalise and harmonise the different segments and 
practices in the European banking sector, putting an end to the traditional distinction between investment and commercial banking, abolishing restrictions on the entry of new agents and aligning prudential requirements for the sector with the 1989 Basel Accords. European integration was therefore central to the entire process. As Pinho (1997: 2) states: 'without the need for alignment with single market legislation, the deregulation of the banks would have been much slower and probably less extensive'.

The removal of all national controls over the international circulation of capital, reflected in the full convertibility of the escudo, was the culmination of the process of transformation of the financial sector. It contributed to attract foreign capital, helping to peg the exchange rate of the escudo, and generating significant revenue from privatisations. The changes in the exchange rate policy in turn meant the substitution of the goal of competitiveness by a disinflationary target, in line with the strictures of the European Monetary System and the Exchange Rate Mechanism, to which the country adhered in the 1990s (Pinto, 1996). With the active participation of the State, this trajectory illustrates an active political commitment to a process of integration increasingly guided by market forces and, in particular, by finance.

The processes of bank privatisation and financial liberalisation, which were basically completed at the beginning of the 1990s, and the nominal convergence trajectory culminating in adherence to the Euro - all contributing to the overvaluing of the escudo - were decisive factors in transforming the Portuguese economy into a financialised economy. Indeed, the official justifications and optimistic evaluations that underpinned the strategy for joining the Euro explicitly underline the aim of expanding the financial sector, perceived as being in the vanguard of 'modernization' (Barbosa, 1998). The remarkable decrease of real interest rates was then seen as the most relevant sign of the successful insertion of national finance in international financial markets. The expectation was, on the one hand, that it would allow firms to accelerate capital accumulation, taken as a pre-condition for future increases in overall productivity; and, on the other hand, that it would favour accumulation of wealth on the part of households, particularly through the purchase of housing stock. From indebtedness levels below the European average in the mid-1990s, Portuguese households and firms were geared to the top in the first decade of the Euro, with levels similar only to the UK and Ireland.

The policy of nominal convergence, as part of the construction of the single European currency, ultimately created conditions for future troubles. Portugal, in contrast to Spain, entered the Euro with an overappreciated exchange rate and with an already unbalanced economy (Garcimartín et al., 2010; Leão and Palacio-Vera, 2011). A huge current 
account deficit started to mount, since the government no longer had available the traditional means to manage it, having previously relied on devaluation to boost its exports and solve its balance of payments problems (Ferreira do Amaral, 2006). The strong Euro aggravated this problem further. In a context marked by continuing downward pressure on prices, Portuguese firms, mostly price-takers when operating internationally, saw a decrease in their profit margins. Incentives were thus geared towards the profitable non-tradable sectors of the economy, less exposed to foreign competition - from construction to retail and privatised utilities - but heavily inserted internationally. The banking sector played a pivotal role in these structural transformations, channelling foreign credit, directly or indirectly (i.e. through households), to these sectors. But before moving to the analysis of the relation between the banking and the non-tradable sectors, a closer examination of the recent evolution of the banking sector is in order.

\section{THE RELATION BETWEEN NATIONAL AND INTERNATIONAL FINANCE}

The rise of finance-to-finance lending is of paramount importance to understanding financialisation. In the Portuguese case, cross-border lending is particularly relevant to explain the insertion of the economy in the international financial sphere, as this has been the preferred channel of foreign financial investment over the past twenty years. Indeed, crossborder loanable capital flows between the Portuguese banking sector and foreign financial agents grew from 9 billion to almost 50 billion euros between 1993 and 1999 (Figure 1).

While this growth was balanced between assets and liabilities until 1999, Portuguese banks' assets and liabilities started to diverge during the 2000s, with the latter growing at a much faster pace reflected in the concomitant widening of the current account deficit. It mirrored, on the one hand, the growing negative net investment position of the country. And it signalled, on the other hand, the unconstrained access of the Portuguese banking sector to foreign debt markets until the 2008 international crisis, which helps explain the absence of classic balance of payments crises typical of peripheral countries. These capital inflows were also driven by real interest rate differentials during the new millennium, favouring the domestic demand for new loans. Interest rates and inflation converged during the nineties (both part of the Maastricht Criteria), but the creation of the single currency interrupted this convergence process. Despite having a common monetary policy, with inflation being the exclusive responsibility of the ECB, inflation differentials rose between the core and the European semi-periphery. ${ }^{5}$ 
Bank credit inflows to Portugal not only changed in magnitude but also in content, noticeable in their maturities. During the 1990s, the growth of credit flows was dominated by short-term loans (Figure 2), mainly in the form of money-market instruments. But since 2000, after the creation of the euro, long-term funding (mainly in the form of bonds and notes) surpassed short-term flows.

This difference in maturities is common to other early experiences of financialisation, being, in a first phase, associated with the proliferation of new short-term financial instruments that promote market liquidity T-bonds on repos, commercial paper, certificates of deposit, promissory notes, etc. - through money markets, as happened for example in the USA in the 1980s (Gindin and Panitch, 2012). These financial claims are only granted among financial institutions, and are subsumed under the evaluation criteria of payment probability. This involves a homogenisation of loanable capital that 'cuts across economic and geographical areas and makes it possible for idle money funds to acquire a common and general character across society' (Lapavitsas, 2003: 83). Credit rating criteria, internationally defined, act here as a unique set of information wherein all the relevant dimensions are integrated, submitting all the sectors, countries or individuals. Such homogenisation of underlying social relations in credit allows for money markets to prevail over context-specific realities. With a new-born private and liberalised banking sector, this has been the case too in Portugal since the 1990s.

Moreover, as pointed out by Gabor (2010), in her analysis of the recent evolution of Eastern European banking sectors, the pivotal role of securitised money markets was typically the outcome of a changing relation between banks and central banks. In the face of the excess of liquidity coming from abroad, central banks in this region resorted to sterilisation operations that further promoted bank securitisation operations. Central banks induced not only the regulatory standardisation of financial practices that allowed these cross-border flows but also acted as active participants in the moulding of these markets. In fact, the role of central banks in financialisation should not be understood as an aberration in the newly liberalised credit markets, but instead as a consequence of their role in the credit system. Central banks need to support every financial liability in the economy, converting money market instruments into currency and reserves. Hence, there cannot be a functioning money market without a credible and robust intervention of central bank money. Without it, credibility can be damaged to the point of collapsing the credit system (Lapavitsas, 2003). However, in Eastern European countries, the role of central banks was constrained by the need to accumulate international reserves in order to sterilise capital flows. This was also the case of Portugal during the 1990s, when a rising current account deficit led the accumulation of foreign exchange reserves. 


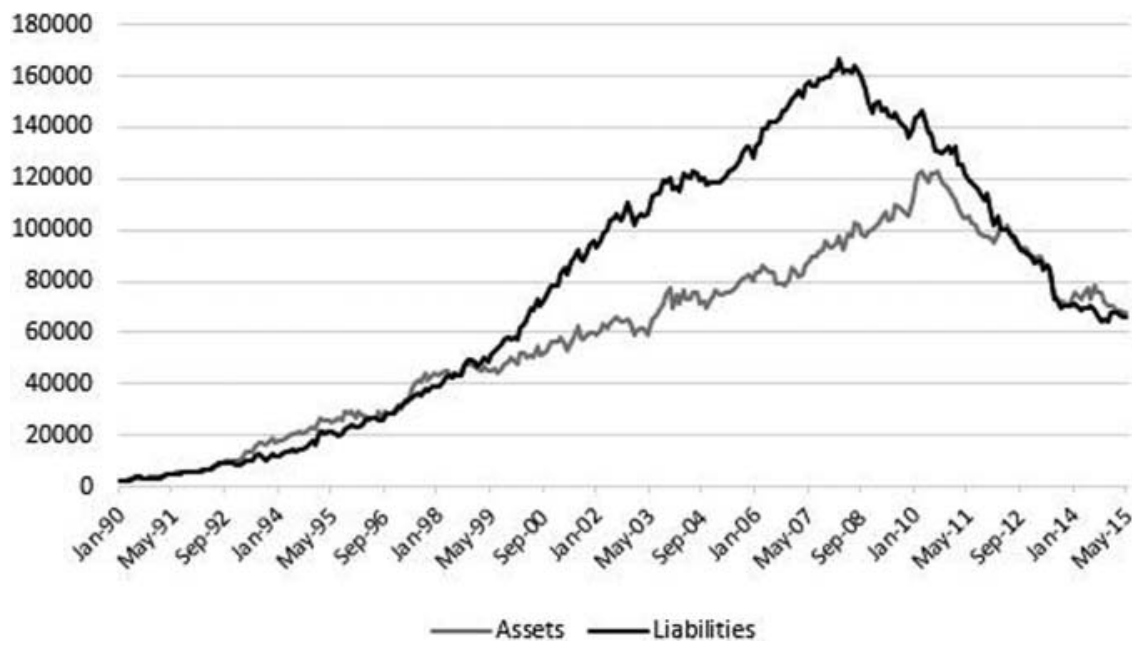

Figure 1 Bank liabilities and assets with rest of the world agents, 1990-2015 (Source: Bank of Portugal, million euros).

With the Euro and its own powerful central bank, the European Central Bank (ECB), the profile of banking credit flows changed, and longterm bonds and notes became the preferred form of indebtedness of the Portuguese banking sector with the rest of the world. The advantage of having access to these debt markets is apparent as it involves fewer costs,

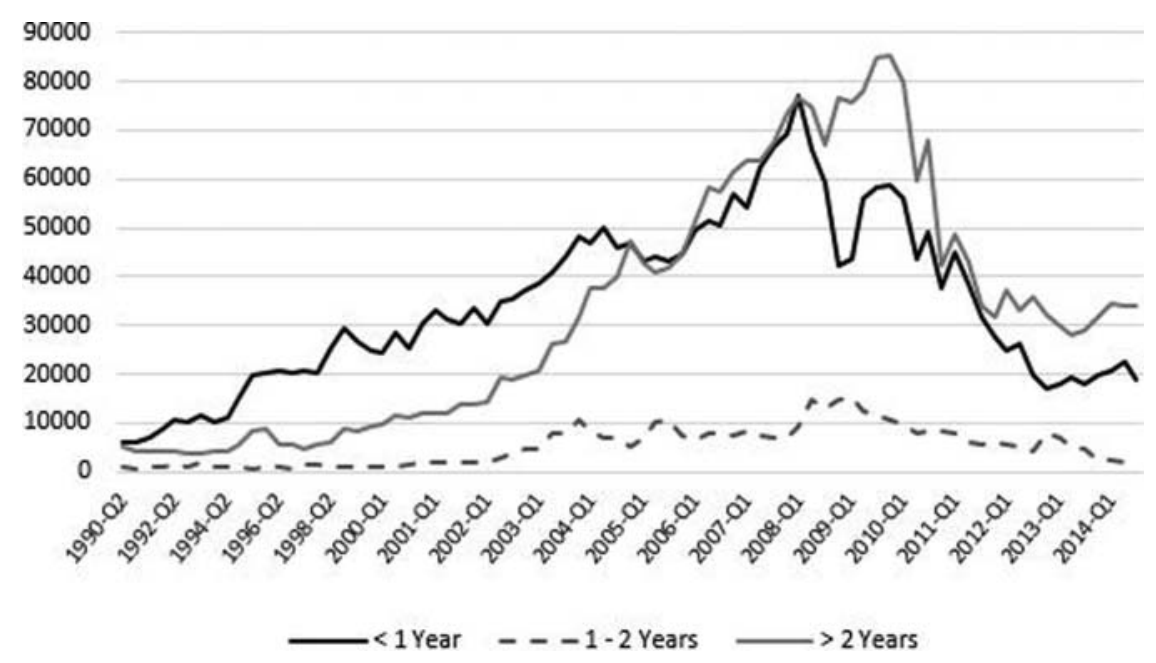

Figure 2 Foreign bank credit inflows by maturity, 1990-2014 (Source: BIS, million dollars). 
thus further enabling the leveraging and profitability of their balance sheets. At the same time, lenders' risk decreased since the single currency eliminated currency risk. Moreover, ECB independence from political power and its mandate devoted to target an inflation rate of no more than $2 \%$ enhanced trust among financial agents in the real value of their future promises to pay.

Coinciding with the creation of the Euro, mortgage securitisation also had a role in expanding credit facilities in Portugal, most importantly by serving as collateral in the ECB's refinancing operations. Created legally only in 1999, under Decree-Law n ${ }^{\circ} 453 / 99$, the first loan securitisation operation was carried out in December 2001. The amount of loan securities issued by Portuguese banks would reach 26 billion euros in 2011, with 39 securitisation funds operating on the market (CMVM, 2012). The scale, sophistication and variety of financial instruments available to the Portuguese banking sector shows that, despite its semi-peripheral position, banks benefited from (long-term) funding only available to the most financialised core countries. Hence, membership in the European and Monetary Union (EMU) contributed to the deepening of financialisation processes during the 2000s, going beyond the pattern of financial integration shown by peripheral countries.

The role of the EMU becomes even more salient when analysing the nationality of foreign bank credit flows into the country. Bank credit was dominated by inflows from other Eurozone countries: from Spain, with which the Portuguese economy was increasingly integrated, and the major financial powerhouses of the Eurozone, Germany and France. Although rising, inflows from other major financial centres outside the EMU, such as the UK and the USA, were not as significant (Figure 3).

This pattern shows not only the importance of the single currency, backed by the ECB, in granting the needed credibility of the Portuguese banks, but also the close relation between financial accumulation and the general dynamic of capital accumulation in Portugal. Indeed, the inflows of credit have their origins in the countries with which Portugal has more intense trade relations, and thus current account deficits, most notably Spain. Cross-border credit was thus intertwined with consumption and investment between Portuguese households and non-financial firms and their suppliers within the Eurozone. The foreign and domestic national banking sectors acted as crucial mediators as they benefited from their domestic position in terms of information gathering and power in their relation with other sectors. While the common financial architecture fostered cross-border lending, the close relation between financial flows and trade relations among European countries indicates that, from its inception, the EMU did not succeed in creating a common securities market where the national origin of capital would be irrelevant. The Euro crisis of 2011 ultimately exposed the fiction of totally integrated financial 
markets, with the sudden drop of capital flows from the core to the least developed EU countries, which cannot be justified by the financial health of particular agents, revealing instead the fragmentation of national financial markets.

\section{FINANCE AND THE NON-FINANCIAL SECTORS OF THE PORTUGUESE ECONOMY}

The securitisation of Portuguese public debt - Treasury bills and bonds - has been the backbone of further financial developments, as has been the case in most developed economies (Gindin and Panitch, 2012). It has allowed the creation of exchangeable collateral essential for money market liquidity operations among financial agents and for modern monetary policy open-market operations. This strategic choice was coupled with another, also made within the EMU framework: the opening up of the public debt market to foreign investors, which further consolidated the insertion of Portuguese banks in the international circuits of finance. Portuguese banks were further helped from the late 1990s onwards in accumulating a net negative financial position with the rest of the world through the supply of this internationally accepted collateral.

Portuguese public debt thereby became increasingly internationalised. In $2008,80 \%$ of public debt was held by foreigners, $50 \%$ was held by foreign banks and $28 \%$ by other foreign institutional investors (pension, investment and hedge funds), (Caldas et al., 2012). This deteriorated the State's investment position in the first decade of the Euro - from a negative position of $29 \%$ of GDP in 2001, it rose to $60 \%$ in 2009 (calculated from international investment position statistics; BdP, 2015), nonetheless being somewhat contained by financial engineering strategies to avoid the rise of public deficits (e.g. public-private partnerships). However, the growing dependence and therefore vulnerability to international finance partially contributed to the financial stress observed in the immediate aftermath of the international crisis. As has been pointed out (e.g. De Grauwe, 2011), while the semi-peripheral States of the Eurozone appeared to have borrowed in a domestic currency at very low interest rates, it is as if they had in fact borrowed in a foreign currency over which they had no control. Thus, the presumed low level of risk, and hence of defaulting, allowed an overextension of loans from core banks to the EU periphery, both in the public and private sectors.

Benefiting from the increased sophistication of the newly liberalised financial system and from the privatisation of major Portuguese nonfinancial firms during the 1990s, major Portuguese companies began to access international capital and debt markets and started to accumulate financial assets. These assets grew from around 29 billion euros in 1994, to 160.5 billion euros at current prices, in 2013, most notably in the form 


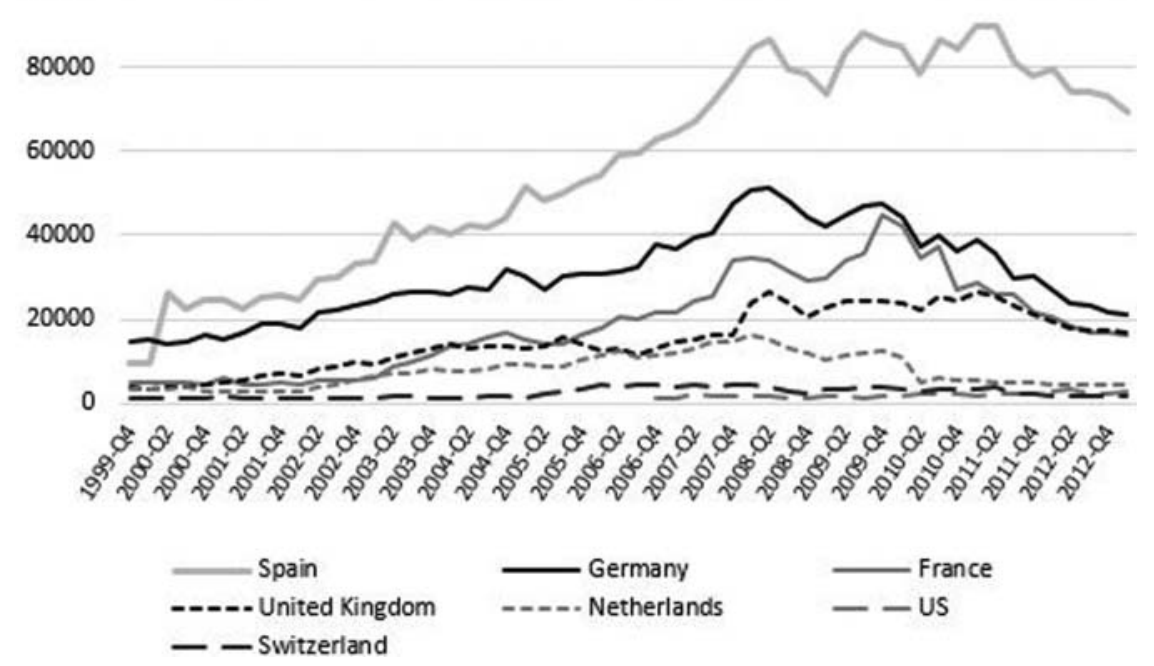

Figure 3 Foreign bank assets in Portugal by nationality, 1999-2013 (Source: BIS, non-consolidated, million dollars).

of shares in other companies, which grew from 5.3 billion euros to 40 billion euros in the same period (consolidated, current prices, national financial accounts statistics; BdP, 2015). However, this engagement with financial markets did not represent an accumulation of net financial assets (or of financial profit, for that matter). On the contrary, the net financial position of Portuguese firms deteriorated from -60 billion to a record negative position of -252 billion euros in the same period (consolidated, current prices, national financial accounts statistics; BdP, 2015). The negative position of non-financial firms can be partially attributed to the issuance of shares (whose importance in balance sheets depends on market fluctuations) and debt securities, such as bonds. However, (bank) loan is the liability that most contributed to this negative position (consolidated, current prices, national financial accounts statistics; BdP, 2015). Thus, the rising financialised profile of Portuguese non-financial firms did not imply a turning away from banking credit, but, on the contrary, a strong and growing dependence on it. And this dependence is mostly related to the domestic banking sector whose loans to domestic nonfinancial firms has grown at a very fast pace since the beginning of the 1990s (Figure 4).

Far from being evenly distributed across all sectors, the boom in banking credit to non-financial firms was highly concentrated. The manufacturing sector, which at the beginning of the 1990s absorbed almost $40 \%$ of all loans granted to business, saw this percentage drop by half in the 2000s (Figure 4). In contrast, bank credit to construction and 
real estate activities, which represented about $10 \%$ of the entire business debt in 1992, reached almost $40 \%$ in 2008 (Figure 4). This reflects the move of domestic capital to sectors protected from international competition in the new context of a strong currency that penalised the tradable sectors such as manufacturing. The Portuguese banking business thus changed both in size and content. These transformations were further encouraged by the adoption of international banking regulations that favoured the financing of homeownership through mortgages (considered the most secure form of credit since they are based on a durable asset as collateral), and thereby the up-stream activities of construction and real estate. Continued public investment in infrastructures further favoured these sectors. Even if the Maastricht fiscal criteria and the Stability Pact constrained public investment, various financial engineering arrangements, such as the creation of State owned enterprises or Public Private Partnerships, allowed for averting the registration of public investment in infrastructure as public expenditure (Teles, 2015). This financial engineering, primarily engendered by the banking sector, allowed for the rise of aggregate investment in the 1990s, pulled by the housing and construction boom of that period, having attained $28 \%$ of GDP in 2000. But this investment would soon drop and stagnate around $23 \%-24 \%$ of GDP from then up to the crisis. This evolution reflected not so much a submission to financialised short-term investment time-horizons, as a form of financial mimicry, but mainly a slow burn crisis in the domestic construction sector, starting in 2001, beleaguered by problems of housing oversupply (Santos et al., 2015).

As domestic investment stagnated, foreign direct investment by Portuguese firms abroad started to rise consistently, from around 20 billion euros at the beginning of the 2000s to more than 50 billion euros at the end of the decade (current prices, International Financial Position Statistics; BdP, 2015), indicating the search for new foreign markets by major Portuguese corporations. Using their holding companies, they benefited from eased access to cheap loans in a strong currency (the Euro) to expand to new markets abroad, especially outside the Eurozone, such as in the Portuguese-speaking countries Angola and Brazil.

If the evolution of the banking business in Portugal differs from that of the US and UK banking in its relation with non-financial firms, the same cannot be said of the relation between banks and households. Similarly to core EU countries, household debt grew, already in the second half of the 1990s. This was promoted by various policy changes including: those relating to the creation of the EMU, inducing a significant decline in real interest rates and the expansion of foreign loanable capital; regulatory changes in the banking sector at EU level, such as those implemented by the Basel Accords, inducing a more favourable treatment of mortgage risk (Allen, 2004); and the promotion of capital markets through the 


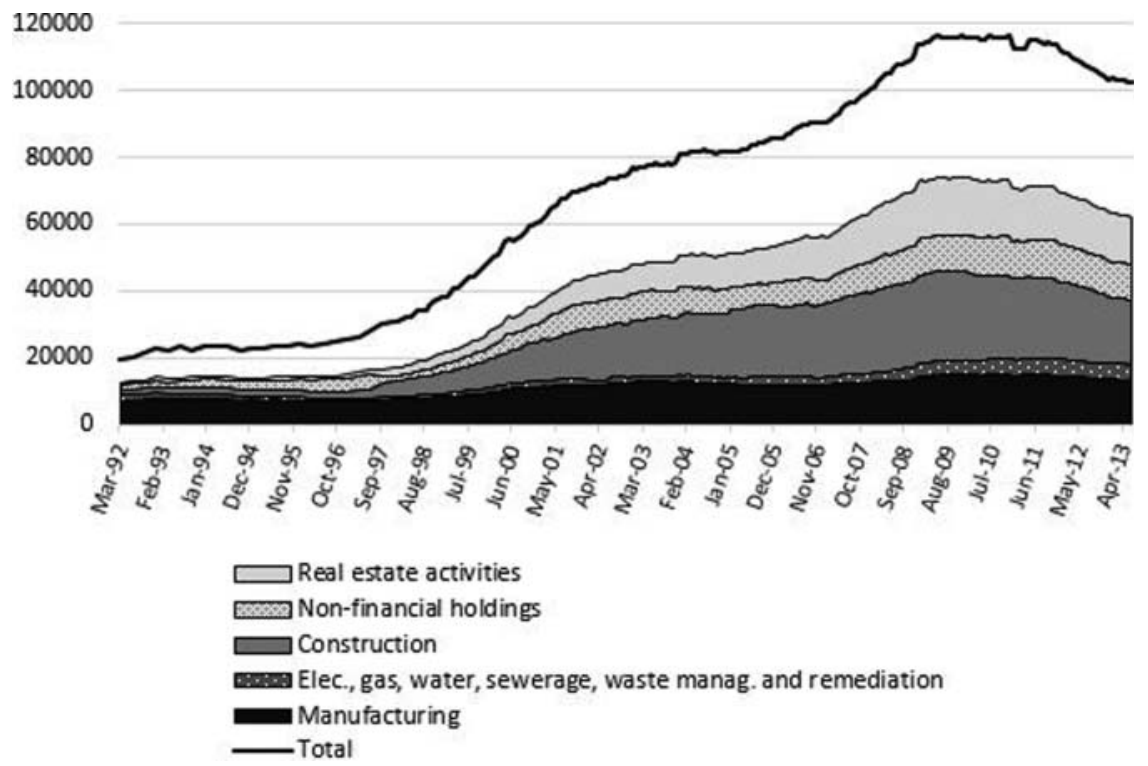

Figure 4 Composition of bank loans to non-financial firms, total and by selected sectors, 1992-2013

(Source: Bank of Portugal, million euros).

introduction of the securitisation of mortgage loans (Aalbers, 2008). The shift of lending towards households during the 1990s is impressive, going from around $45 \%$ of bank lending to non-financial corporations in 1992, to 115\% in 1999, having grown more slowly since then (Monetary and Financial Statistics; BdP, 2015). The centrality of household debt in financialisation is the issue to which we now turn.

\section{THE UNEQUAL ENGAGEMENTS OF PORTUGUESE HOUSEHOLDS WITH FINANCE}

The extraordinary growth of household debt over the past two decades, and of its weight in the overall level of indebtedness of the (non-financial) private sector, provides a remarkable synthesis of the unbalanced semiperipheral nature of the Portuguese financialisation processes. It conveys, in particular, the financialisation of the housing sector as banks not only financed the construction of family dwellings but also home purchases, thus controlling their production and provision. Indeed, household debt is likewise the outcome of European integration, allowing unprecedented access by the Portuguese banking sector to European credit markets, as noted above, making credit available to households at low interest rates. And it is a manifestation of the structural imbalances of the Portuguese 
economy, favouring the non-tradable construction sector, in general, and the production of new homes, in particular, as the bulk of household debt pertains to housing loans.

In Portugal, household debt grew from 35\% of disposable household income in 1995 to reach its highest value of $131 \%$ in 2009, declining since then and representing 118\% of disposable household income in 2013 (Eurostat, 2015a). The rise in Portuguese household debt is easily identified with housing loans. It not only constitutes the main portion of household bank debt, but its weight in total debt increased from 70\% in 1995 to $80 \%$ in 2009 (ECRI, 2014). The construction of household dwellings rose dramatically in the same period, when the number of homes built per annum tripled from 40.000 in 1995 to 120.000 in 2002 (INE, 2015a). This growth in housing construction and mortgage debt corresponded to a rise in the proportion of property owners relative to tenants, with homeownership representing 73\% of accommodation in 2011, growing from 65\% in 1991 (Pordata, 2015).

The extraordinary growth of household debt over the last two decades, reaching levels comparable only to those of the countries of the North and Centre of Europe, offers a clear illustration of the magnitude of socioeconomic transformations in Portugal. In 2009, when the crisis hit, Portuguese households were among the most indebted in Europe. In this year, the average level of household debt for the 18 Euro countries, as measured by the percentage of household debt to disposable household income, was 98\%, while it reached $131 \%$ in Portugal, surpassed only by six other EU countries (Eurostat, 2015a). ${ }^{6}$

Besides the financialisation of the Portuguese economy within the context of EU integration, the traditional weakness of the Portuguese Welfare State, together with a housing policy focused on the promotion of private ownership, help to explain the magnitude and content of Portuguese household debt. ${ }^{7}$ Already prior to membership of the EEC, ownership rates were high in EU terms, as State intervention favoured private forms of provision (Santos et al., 2015). The financialisation of the Portuguese economy ultimately provided the conditions for the success of a policy model focused on homeownership through the use of credit, which from the second half of the 1990s onwards became cheap and plentiful. In the first years of the millennium, subsidies associated with loans for permanent homeownership and tax incentives granted under the Income Tax Code for the acquisition, construction or improvement of private housing reached $80 \%$ of total public funding on housing (CETISCTE et al., 2008).

Thus, rather than being associated with the retreat of the Welfare State, as has been argued for other contexts, in Portugal the evolution of household debt is more directly the result of financialisation. This nonetheless points to the importance of relevant systems of provision and broader 
welfare provisioning, which are shaped by country-specific social, political, economic, and historical factors (Bayliss et al., 2013), entailing differentiated extents, natures and uses of finance. In the Portuguese case, the almost non-existent public provision of housing explains by and large the extent and magnitude of household debt. Yet the State has played a critical part, ensuring the synchronic evolution of demand to the supply of credit to households through fiscal incentives to home purchase with credit.

However, household engagement with finance is not a transversal phenomenon within Portuguese society. Unlike recent household credit expansion in the American subprime market, this expansion was not directed at all at the lower social classes at greater risk of defaulting, but to households with higher incomes and better guarantees of financial solvency. In 2010, only 38\% of Portuguese families were in debt, approximately $25 \%$ had a loan on a household home, 3\% had mortgages for properties other than their home, and $18 \%$ had loans not secured by property (ECB, 2013). Moreover, the level of household involvement in the debt market rises in line with income level, ranging from $18 \%$ for the lower income quintile to $57 \%$ for the highest (BdP and INE, 2012).

The fact that household debt consists mainly of mortgage loans and that it is concentrated in higher-income households exposes the unequal access to and the unequal impact of finance on households. For the Portuguese middle to upper classes, homeownership has emerged as the best option for meeting accommodation needs. Benefiting from low interest rates and long maturity periods on their housing loans, these households saw a reduction of their housing costs (when compared with the rental market) and accumulated wealth. This is clearly evidenced by the difference between the cost of a mortgage and of paying rent. In 2013, only 7\% of families with mortgages were bearing an excessive burden of expenditure on housing (i.e. over $40 \%$ of the available household income), whereas the figure was $35 \%$ for households who were renting the household home (Eurostat, 2015b). The extraordinary expansion of household debt should thus be understood as the easiest and cheapest way for the wealthier households to gain access to housing. Departing from very low debt levels, this rise of indebtedness was not only generally sustainable in respect of a household's ability to pay, but was also a relatively safe way to accumulate wealth, despite the modest drop in housing prices in recent years. With most of these mortgages contracted at variable rates indexed to the interbank rate Euribor, monthly repayment amounts have followed the decline of ECB interest rates since 2009 allowing for a significant reduction in levels of mortgage loan repayments (INE, 2015b).

The participation of Portuguese households is even more unequally distributed in financial assets markets. In 2010, the top income decile concentrated all financial assets, where $33 \%$ of these households held 
tradable assets (mutual funds, bonds and shares) and $43 \%$ held voluntary private pensions or whole life assurance, while the bottom income quintile held, respectively, $1 \%$ and 3\% of the same assets (BdP and INE, 2012). This means that high-income households have substantially higher rates of participation in financial markets, both as debtors and holders of financial assets. The concentration of specific financial liabilities such as mortgage debt, and of financial assets such as mutual and pension funds, in high-income households suggests that they have a balanced and beneficial relation with finance. This is so not only because financial liabilities are contracted on more favourable terms and can be converted into real wealth, but also because these households have a more diversified and balanced set of financial assets, thus being better able to hedge their portfolios against financial volatility. In contrast, low-income households tend to contract debt with higher interest rates for the purchase of consumer goods, having fewer means to deal with liquidity or solvency problems, being more vulnerable to personal and social contingencies that compromise their wage income. By benefiting the high-income households more and in relevant areas of provision, such as housing and retirement, financialisation is further detrimental to the most vulnerable segments of the population in promoting and reinforcing private and commodified forms of provision.

The rapid expansion of debt among Portuguese households over the past two decades has been associated with low levels of default. It was the crisis - and the consequent drop in household income and overall increase in the cost of living - that led to bad debt in bank portfolios. Reflecting the differentiated engagement of households with finance, the default rate on credit for consumer goods and other purposes rose fastest, from around $6.6 \%$ in 2009 to $14 \%$ in 2014, while the default rate for housing loans remained relatively contained, increasing from $1.6 \%$ to $2.7 \%$ in the same period (BdP, 2015).

It was therefore essentially the crisis itself that revealed the seriousness of debt incurred by Portuguese families and made them more vulnerable to the economic and financial instability of the country. Vulnerability to debt problems was not caused by the bursting of inflated mortgage markets, leading to the fall in housing prices as in the USA and to a lesser extent Spain. It was first and foremost caused by the rise in unemployment and the sudden lack of income caused by austerity conditionality imposed by the European Union and the IMF and endorsed by the Government.

Thus, the claim that it has been the growth of income inequality and the rollback of the State that have forced households to engage with finance to fill the gap between income and acquired standard of living does not apply to the Portuguese case, as has been argued for the USA and the UK (see, for example, Barba and Pivetti, 2009; Cynamon and 
Fazzari, 2008). And while households have been a new source of revenue for the banking sector, what we observe is by and large a shift in the transfer of income stream from private landlords, positioned in a shrinking market, to banks benefiting from the rise of homeownership rates. Hence, contrary to Lapavitsas's (2009) hypothesis of financial expropriation, the financialisation of households, at least in the Portuguese case, should not be taken as a detrimental relation across all income brackets but as a phenomenon that exacerbates existing income inequality, resulting in the concentration of wealth and capital within the financial sector.

\section{TOWARDS A SEMI-PERIPHERAL CONCEPTUALISATION OF FINANCIALISATION}

Critical political economy should devote more attention to the concrete institutional underpinnings of the recent rise of finance and to power relations beyond the Anglo-American world. This is precisely what this paper has done through scrutiny of the content of financialisation in the semi-peripheral Portuguese economy, bringing to the fore the role of the EU. In so doing, it has shown how and the extent to which Portugal benefited and, at the same time, was constrained by the direct and indirect EU rules that promoted the international financial sphere.

Having described the main features of the financialisation of the Portuguese economy and society, we are now in a better position to elaborate on the theoretical understanding of the context-specific nature of semiperipheral financialisation aimed as a contribution to this emerging body of literature. We begin by synthesising the main differences between core and semi-periphery and between semi-periphery and periphery. Based on the Portuguese case, we then highlight the main features of the relation between finance and other economic agents, national and international, in semi-peripheral contexts and underline the role of the State in shaping them.

In contrast to core countries, in the Southern European semi-periphery the major institutional transformations involving finance occurred at a later stage, evolved at a faster pace and were strongly determined by external factors, even if mediated by the enabling role of the State (Gambarotto and Solari, 2015). In Portugal in the early 1980s, within what was then considered a highly 'repressed' financial system, the scale and speed of these transformations were remarkable and directly associated to the process of European integration. The insertion of the national financial sector in the international circuits of finance had as its main outcome the growing accumulation of external debt from the 1990s onwards, with no parallel in either core countries or countries with similar economic structures. Portuguese banks successfully positioned themselves in the new emerging monetary and financial hierarchy associated with the 
construction of the EMU. This has meant the formation of 'a hierarchical alliance of sovereign states' so as to produce 'a new form of world mon$\mathrm{ey}^{\prime}$, benefiting particular fractions of capital both at the national and at the international levels (Lapavitsas, 2013: 300). This not only goes beyond the 'Americanisation of Finance' (Gindin and Panitch, 2005), by showing the role of other agents and means by which structural power has been harnessed in global financial markets (Konings, 2007); it also shows that these have been central to account for the dynamics of financialisation and crisis in semi-peripheral EU countries such as Portugal.

Although Portugal shares many features usually identified with peripheries, namely rising capital inflows in the immediate aftermath of financial liberalisation and privatisation, rising real exchange rates and external indebtedness (Becker et al., 2010), relevant differences apply. Having joined the Euro, Portugal benefitted from cheap and abundant capital, consisting mostly of banking loans. It did not need to hold high exchange reserves, nor did it need to keep high interest rates to attract foreign capital, as did other peripheral and semi-peripheral countries. However, facing high real exchange rates, resulting from a backward economic position and rising productivity differentials with the Eurozone, credit was directed to sectors which were relatively insulated from foreign competition, such as construction and real estate. This has meant that the extraordinary influx of capital, even if at a low cost, has not resulted in positive structural transformations in the economy. On the contrary, a decaying manufacturing tradable sector was progressively substituted by the construction and real-estate sectors. High external and unsustainable debt is thus not so much related with the cost of capital per se but largely with the insertion of its less competitive economy in the international arena and resulting intertwining with international finance.

The context-specific nature of semi-peripheral financialisation in Southern European countries stems by and large from the hybrid nature of these economies, combining elements of relatively backward structures with a rapidly modernised financial sector fully articulated with core financial centres. They share many features that are manifestations of the same processes - the predominance of loanable capital from external sources, capital accumulation geared towards domestic non-tradable sectors, rising levels of household debt, and a State overly dependent on foreign funding (Orsi and Solari, 2010). But Southern European countries also differ in many respects. For example, while external debt rose in all countries, in Portugal and Spain this was mostly private whereas in Greece it was mostly public (Lapavitsas et al., 2012). And while household debt rose dramatically in Portugal and Spain over the last two decades, due mainly to the evolution of housing loans, only the latter displayed continued high levels of investment in the sector feeding a 
housing bubble in the 2000s (López and Rodríguez, 2011; Santos et al., 2015). This partially explains why the Euro is associated, in Portugal, with prolonged economic stagnation before the crisis; a feature shared only with Italy within the Eurozone, although the latter did not register the same high levels of external debt.

As regards the relation of finance with non-financial firms, and in contrast to other experiences in core countries in Europe and elsewhere, the Portuguese case shows that the development of capital markets did not imply a 'crowding-out' of bank funding (cf. Lapavitsas and Powell, 2013). It also shows that financialisation did not involve the shortening of the time horizons for investment, taking the more profitable short-term financial investment as the new benchmark and adopting a corporate governance model based on short-term results (Stockhammer, 2004). In Portugal, domestic securities (whether equity or debt) markets have been and still are relatively underdeveloped.

The insertion of Portuguese banks in international financial markets allowed non-financial firms to access foreign funds, contributing to unprecedented and exceptionally high levels of private debt. Rather than reflecting the mere submission of the 'real economy' to financial interests, non-financial firms have simply adjusted to the new financialised context, developing a symbiotic relation with financial actors, investing, domestically and abroad, in accordance with the opportunities and incentives offered by context-specific socioeconomic conditions.

From this it follows that increased access to and engagement with capital markets should not be taken as defining features of financialisation in the Southern European semi-periphery. The Portuguese case instead suggests that the financial operations of non-financial firms are part of an overall process of economic restructuring whereby major corporations mutated into transnational industrial-financial groups, managing delocalised production and benefiting from financial engineering in their domestic and international operations. This was most significantly the case in the non-tradable sectors both domestically and internationally; in the latter case through investments outside the Eurozone (Teles, 2015).

The Portuguese case also offers a seemingly different interpretation of the rising involvement of households. The extraordinary rise of household debt undoubtedly conveys households' increasing dependence on finance to access a host of goods. It has also meant that wage income has become an ever more important source of revenue for finance. And it likewise exposes an asymmetric power relation between banks and households, unfavourable to the latter. However, the contents and meanings of these relations are not comparable to those that have been identified in the UK or USA.

In Portugal, the shift of finance towards households is not explained by the growing reliance of non-financial firms on capital markets for their 
financing since lending to firms never ceased to grow. Nor can the rise in household indebtedness be justified by the retreat of the Welfare State, rising inequality and wage stagnation, increasingly compelling low to medium income families to resort to credit to access fundamental areas of social provision. As we have seen, the growing involvement of households with finance cannot be attributed to the retrenchment of the State in housing provision since public provision in this domain of social policy has been historically residual. Until the 2008-09 crisis, Portugal had in effect registered social progress on many fronts, resulting in steady declines in income inequality (Rodrigues, 2012).

Moreover, the rise of household indebtedness is concentrated on highincome households. These households not only tend to have higher rates of participation in debt markets, but they have even higher participation rates in financial asset markets, indicating that their engagement with the financial sector is generally made on both sides of the balance sheet, with assets more than covering liabilities. Thus, rather than being associated with attempts at preserving a previous standard of living, household debt has been first and foremost a means through which the higher stratum has strengthened its relative advantage, reproducing and consolidating corresponding inequalities. However, the crisis, namely the austerity policies pursued since 2011 as part of the conditionality of the financial assistance by the Troika, is leading to the retrenchment of public provision, particularly in healthcare and social security, resulting in rising inequality. The effects of the deterioration of living conditions on household engagement with finance are as yet uncertain. But as the national banking system recovers with the help of European institutions, in a rather indebted and stagnated economy, it might be expected that household participation in financial markets will become even more concentrated among the better off, instead of moving progressively towards the inclusion of the lower echelons of society.

All these trends were shaped by and simultaneously shaped the nature of the Portuguese State. Under European influence, namely through the national transposition of a progressively market-creating and marketconforming regulatory apparatus in the financial sphere, successive Portuguese governments played a role in the insertion of the country in the international financial circuits, thus mediating between the European and the domestic levels. One of the major transformations in the country was thus the loss of important elements of sovereignty in the economic and monetary realms as European integration moved forward. The dire consequences of these changes were mitigated, or disguised, until the crisis of 2008-09, due to easy access to funding at low interest rates. The financial crisis then morphed into a crisis of public debt, revealing the full extent of State dependence on external funding, whether from financial markets or, in their absence, from official creditors with their rigid 
conditionality. The hierarchical nature of the Euro, as a fragile form of quasi-world money without the backing of a real State, has ultimately been brought to the fore.

To conclude, this paper presented the main features of the financialisation of the Portuguese economy and society by focusing on the relation between finance and external and domestic economic agents. It underlined the context-specific nature of semi-peripheral financialisation processes, and of underlying social relations, by examining: (1) the historical and context-specific international insertion of Portugal as a semi-peripheral country in international financial markets, as external agents are the main driving force in promoting financialisation in the periphery and semi-periphery; (2) the impacts of international financial integration on the economy through changing the incentives of national (financial and non-financial) agents; (3) the impacts of international financial integration on individuals and households, taking due account of how finance interacts with relevant systems of provision; and (4) the role of the State in mediating between the international and domestic levels. Based on the Portuguese case, the paper then proposed a theoretical framework for the analysis of the context-specific nature of semi-peripheral financialisation processes that combines and integrates all these features, that aims at avoiding unwarranted generalisations while going beyond mere descriptive exercises. The concept of semi-peripheral financialisation put forward signals differences in form and content relative to financialisation processes in core countries. It underlines the more predominant and critical role of bank loanable capital in shaping recent changes in semiperipheral countries. It emphasises the role of international finance and its intertwining with domestic agents, including financial institutions, non-financial firms and households, which are crucial adequately to account for variation in financialisation processes in semi-peripheral countries.

\section{ACKNOWLEDGEMENTS}

We are grateful to four anonymous referees for helpful comments and suggestions. Remaining errors are the responsibility of the authors.

\section{DISCLOSURE STATEMENT}

No potential conflict of interest was reported by the authors. 


\section{FUNDING}

The research leading to these results is part of the FESSUD project that has received funding from the European Union Seventh Framework Programme (FP7/2007-2013) [grant number 266800].

\section{NOTES}

1. The term quasi-world money refers to Marx's concept of world money and accounts for the need for a common international means of payment and hoarding (reserves) in the world market. This has been mostly assured by the dollar, which has given the USA the 'ability to exercise monetary policy domestically, to maintain foreign trade deficits and to import and export capi$\mathrm{tal}^{\prime}$. It has also 'spurred financialization in developing countries and systematically transferred value to the US' (Lapavitsas, 2013: 104).

2. They argue that in the peripheries and semi-peripheries, where financial securities markets are less developed, financialisation is more directly associated with the expansion of loanable capital provided by banks, national and international.

3. Notwithstanding the intensification of economic relations with its former colonies (namely, with Brazil and Angola), promoted too by cheap and easy access to loanable capital in a hard currency (the euro), these economic ties have remained of marginal importance to the Portuguese economy as a whole. For this reason the traditional intermediation role between core/empire and periphery/colony (e.g. Wallerstein, 1974) is not taken as significant for the contemporary Portuguese case.

4. After the 2008-09 crisis, the Portuguese banking sector has undergone a new wave of mergers and acquisitions, further intensifying concentration in the sector, now with the increasing participation of foreign capital.

5. In contrast to what was observed in Portugal, in Germany wages grew at a slower pace than productivity. The difference between the unit labour costs of the two countries explains, at least partially, the continued relative loss of competitiveness in Portugal (Lapavitsas et al., 2012).

6. Denmark $(270 \%)$, the Netherlands $(244 \%)$, Ireland (209\%), the UK $(147 \%)$, Sweden (142\%) and Luxembourg (132\%).

7. In contrast to core EU countries, the building of the Portuguese Welfare State is not an outcome of the post-war compromise that aligned economic growth with overall social progress. It is instead a late, post-1974 product of the democratisation of the country, often depicted as a 'southern welfare regime' (Ferrera, 1996) or as a 'welfare society' (e.g. Santos, 1985), supplying limited welfare benefits, and supplemented by more traditional intermediary institutions such as the family.

\section{NOTES ON CONTRIBUTORS}

João Rodrigues is a lecturer at the Faculty of Economics and a researcher at the Centre for Social Studies, both at the University of Coimbra, Portugal. His research interests range from the history of neoliberalism to the recent Euro crisis. He has published on these topics in journals such as Cambridge Journal of Economics, Competition \& Change and New Political Economy. 
Ana C. Santos is a researcher at the Centre for Social Studies, University of Coimbra, Portugal. Her research interests include methodology of economics, experimental and behavioural economics and the financialisation of households. She has published on these topics in journals such as Journal of Economic Methodology, Cambridge Journal of Economics and New Political Economy.

Nuno Teles is a researcher at the Centre for Social Studies, University of Coimbra, Portugal. His research interests range from financialisation studies to development economics. He is one of the authors of Crisis in the Eurozone, London: Verso (2012).

\section{REFERENCES}

Aalbers, M. B. (2008) 'The financialization of home and the mortgage market crisis', Competition \& Change 12(2): 148-66.

Abdelal, R. (2006) 'Writing the rules of global finance: France, Europe, and capital liberalization', Review of International Political Economy 13(1): 1-27.

Allen, L. (2004) 'The basel capital accords and international mortgage markets: a survey of the literature', Financial Markets, Institutions $\mathcal{E}$ Instruments 13(2): 41-108.

Antão, P., Boucinha, M., Farinha, L., Lacerda, A., Leal, C. and Ribeiro, N. (2009) 'Integração Financeira, estruturas financeiras e as decisões das famílias e das empresas' [Financial integration, financial structures and decisions of households and firms], in Banco de Portugal (ed), A Economia Portuguesa no contexto da Integração Económica, Financeira e Monetária [Portuguese Economy in the Context of the Monetary, Financial and Economic Integration], Lisbon: Departamento de Estudos Económicos, pp. 423-561.

Arrighi, G. (1994) The Long Twentieth Century. Money, Power and the Origins of Our Times, London: Verso.

Ashman, S. (2009) 'Capitalism, uneven and combined development and the transhistoric', Cambridge Review of International Affairs 22(1): 29-46.

Banco de Portugal [BdP] (2015) BPstat Estatísticas on line: séries cronológicas; accessed at http://www.bportugal.pt/EstatisticasWeb/(S(3j33hh55kyv v2245i2u3n3bz))/SeriesCronologicas.aspx\#, 21 October 2015.

Banco de Portugal and Instituto Nacional de Estatística [BdP and INE] (2012) Inquérito à situação Financeira das Famílias [Survey to the Financial Situation of Households], Lisbon: Departamento de Estudos Económicos.

Barba, A. and Pivetti, M. (2009) 'Rising household debt: its causes and macroeconomic implications-a long-period analysis', Cambridge Journal of Economics 33: 113-37.

Barbosa, A. P. (org.) (1998) O Impacto do Euro na Economia Portuguesa [The Impact of the Euro in the Portuguese Economy], Lisbon: Publicações Dom Quixote.

Bayliss, K, Fine, B. and Robertson, M. (2013) 'From financialisation to consumption: the system of provision approach applied to housing and water', FESSUD Working Paper Series, no 2, Leeds: FESSUD project.

Becker, J., Jäger, J., Leubolt, B. and Weissenbacher, R. (2010) 'Peripheral financialization and vulnerability to crisis: a regulationist perspective', Competition and Change 14(3-4): 225-47.

Boyer, R. (2000) 'The political in the era of globalization and finance: focus on some regulation school research', International Journal of Urban and Regional Research 24(2): 274-322. 
Caldas, J.; Rocha, S. and Teles, N. (coord.) (2012) 'Conhecer a dívida para sair da armadilha: relatório preliminar do grupo técnico' [Knowing debt so as to get out of the trap: technical group report], Iniciativa para uma Auditoria Cidadã à Dívida [Initiative for a citizen's audit to debt]; accessed at http://auditoriaci dada.info/facebook/docs/relatorio_iac.pdf, 2 March 2015.

CET-ISCTE, IRIC/UP and A. Mateus e Associados (2008) Contributos para o Plano Estratégico de Habitação 2008/2013: Sumário Executivo para Debate Público [Contributions to the Strategic Housing Plan 2008/2013: Executive Summary for Public Debate]; accessed at http://habitacao.cm-lisboa.pt/documentos/ 1234211038E9kPG7ew2Zz82AW0.pdf, 10 March.

CMVM (2012) Relatório Estatístico da Gestão de Ativos em Portugal [Statistical Report on Asset Management in Portugal], 4 ${ }^{\underline{a}}$ quarter of 2011; accessed at http://www.cmvm.pt/CMVM/Estatisticas/Gest\%20Activos/2011_4t/ Pages/2011_4t.aspx, 8 March.

Cynamon, B. and Fazzari, S. (2008) 'Household debt in the consumer age source of growth and risk of collapse', Capitalism and Society 3: 1-30.

De Grauwe, P. (2011) 'The governance of a fragile Eurozone', Centre for European Policy Studies, Working Paper 346, May, Brussels: Centre for European Policy Studies.

Fields, D. and Vernengo, M. (2013) 'Hegemonic currencies during the crisis: the dollar versus the euro in a cartalist perspective', Review of International Political Economy 20(4): 740-59.

Epstein, G. A. (2005) Financialization and the World Economy, Aldershot: Edward Elgar.

European Central Bank [ECB] (2013) 'The eurosystem household finance and consumption survey: results from the first wave, Statistics Paper Series, $\mathrm{n}^{\circ} 2 /$ April, Frankfurt: European Central Bank.

European Credit Research Institute [ECRI] (2014) Lending to households in Europe 1995-2013 - ECRI Statistical package 2013, Brussels: European Credit Research Institute.

Eurostat (2015a), Annual Sector Accounts Database (NASA); accessed at http:// appsso.eurostat.ec.europa.eu/nui/submitViewTableAction.do, 27 February 2015.

Eurostat (2015b), Income and living conditions Database (ILC); accessed at http:/ / appsso.eurostat.ec.europa.eu/nui/submitViewTableAction.do, 9 March 2015.

Ferreira do Amaral, J. (2006) ‘O Impacto Económico da Integração de Portugal na Europa' [The Economic Impact of the Portuguese Integration], Nação \& Defesa [Nation \& Defense] 115: 113-28.

Ferrera, M. (1996) "The "Southern model of welfare in social Europe", Journal of European Social Policy 6: 17-37.

Fine, B. (2010) 'Locating financialisation', Historical Materialism 18(2): 97-116.

Fine, B. (2011) 'Financialisation on the rebound?', mimeo, London: SOAS, http:/ / eprints.soas.ac.uk/12102

Fine, B. (2013) 'Financialization from a marxist perspective', International Journal of Political Economy 42(4): 47-66.

Gabor, D. (2010) '(De)financialisation and crisis in Eastern Europe', Competition and Change 14(3-4): 248-70.

Gambarotto, F. and Solari, S. (2015) 'The peripheralization of Southern European capitalism within EMU', Review of International Political Economy 22(4): 788-812. doi:10.1080/09692290.2014.955518 
Garcimartín, C., Rivas, L. A. and Martínez, P. G. (2010) ‘On the role of relative prices and capital flows in balance-of-payments-constrained growth', Journal of Post Keynesian Economics 33(2): 281-305.

Gindin, S. and Panitch L. (2005) 'Finance and the American empire', in L. Panitch and C. Leys (eds), Socialist Register 2005, London: Merlin, pp. 46-81.

Gindin, S. and Panitch, L. (2012) The Making of Global Capitalism, New York, Verso.

Hardie, I. (2011) 'How much can governments borrow? Financialization and emerging markets government borrowing capacity', Review of International Political Economy 18(2): 141-67.

Helleiner, E. (1994) States and the Reemergence of Global Finance: From Bretton Woods to the 1990s, Ithaca: Cornell University Press.

Instituto Nacional de Estatística [INE] (2015a) Estatísticas das Obras Concluídas [Statistics of Housing]; accessed at http://www.ine.pt/xportal/xmain?x $\mathrm{pid}=\mathrm{INE} \& \mathrm{xpgid}=$ ine_indicadores\&indOcorrCod $=0000077 \&$ contexto $=\mathrm{bd} \& \mathrm{~s}$ $\mathrm{elTab}=\mathrm{tab} 2,9$ March 2015.

Instituto Nacional de Estatística [INE] (2015b) Construção e habitação: Indicadores de Preços na Habitação [Construction and Housing: Price Indicators]; accessed at http://www.ine.pt/xportal/xmain?xpid=INE\&xpgid=ine indicadores\&indOcorrCod $=0004308 \&$ contexto $=b d \& s e l T a b=t a b 2,9 \mathrm{March}$ 2015.

Kaminsky, G. and Reinhart, C. (1999) 'The twin crises: causes of banking and balance-of-payments problems', American Economic Review 89(3): 473-500.

Krippner, G. (2005) 'The financialization of the American economy', Socio-Economic Review 3: 173-208.

Konings, M. (2007) 'The institutional foundations of US structural power in international finance: from the re-emergence of global finance to the monetarist turn', Review of International Political Economy 15(1): 35-61.

Lapavitsas, C. (1997). 'Two approaches to the concept of interest-bearing capital', International Journal of Political Economy 27 (1): 85-106.

Lapavitsas, C. (2003) Social Foundations of Markets, Money, and Credit, London: Routledge.

Lapavitsas, C. (2009) 'Financialised capitalism: crisis and financial expropriation', Historical Materialism 17(2): 114-48.

Lapavitsas, C. (2013) Profiting Without Production: How Finance Exploits Us All, London: Verso.

Lapavitsas, C., Kaltenbrunner, A., Lambrinidis, G., Lindo, D., Meadway, J., Michell, J., Painceira, J, Pires, E., Powell, J., Stenfors, A., Teles, N. and Vatikiotis, L. (2012). Eurozone in Crisis, London: Verso Books.

Lapavitsas, C. and Powell, J. (2013) 'Financialisation varied: a comparative analysis of advanced economies', Cambridge Journal of Regions. Economy and Society 6(3): 359-79.

Leão, P. and Palacio-Vera, A. (2011) 'Can Portugal escape stagnation without opting out from the Eurozone', Levy Economics Institute, Working Paper 664.

López, I. and Rodríguez, E. (2011) 'The Spanish model', New Left Review 69 (May-June): 5-29.

Mendes, V. and Rebelo, J. (2003) 'Structure and performance in the Portuguese banking industry in the nineties', Portuguese Economic Journal 2(1): 53-68.

Nunes, A. (2011) 'The international monetary fund's stand-by arrangements with Portugal. An ex-ante application of the Washington Consensus?', Instituto Superior de Economia e Gestão - GHES, Working Paper 44, Lisbon: Instituto Superior de Economia e Gestão - GHES. 
Orsi, L. and Solari, S. (2010) 'Financialisation in Southern European countries', Economie Appliquée 63(4): 5-34.

Painceira, J. P., (2009) 'Developing countries in the era of financialisation: from deficit accumulation to reserve accumulation', RMF Discussion Papers 4, London: Research on Money and Finance.

Pinho, P. (1997) 'The impact of the single market programme and the preparations in Portuguese banking', Working Paper Series: Faculdade de Economia da Universidade Nova de Lisboa, ${ }^{\circ}$ 312, Lisbon: Faculdade de Economia da Universidade Nova de Lisboa, available at http:/ / fesrvsd.fe.unl.pt/WPFEUNL/ WP1997/wp312.pdf.

Pinto, A. C. and Teixeira, N. S. (2002), 'From Africa to Europe: Portugal and European integration', in Pinto, A. C. and Teixeira, N. S. (eds.), Southern Europe and the Making of the European Union, New York: Columbia University Press, pp. 3-40.

Pinto, A. M. (1996), 'Changing financial systems in small open economies: The Portuguese case', Bank of International Settlements Policy Papers, 1, available at: http://www.bis.org/publ/plcy01.htm.

PORDATA (2015) Base de dados - Portugal Contemporâneo: Habitação, Conforto e condições de vida [Database - Contemporary Portugal: Housing and Life Conditions], accessed at http://www.pordata.pt/Portugal/Alojamen tos+familiares+classicos+de+residencia+habitual+segundo+os+Censos $+\mathrm{t}$ otal++por+ocupantes+proprietarios+e+inquilinos-145, 9 March 2015.

Rodrigues, C. F. (org.) (2012) Desigualdade Económica em Portugal [Economic Inequality in Portugal], Lisbon: Fundação Manuel dos Santos.

Rodrigues, J. and Reis, J. (2012), 'The asymmetries of European integration and the crisis of Portuguese capitalism', Competition and Change 16(3): 188-205.

Santos, B. S. (1985), 'Estado e sociedade na semiperiferia do sistema mundial: o caso Português', Análise Social 87/88/89: 869-901 [State and Society in the Semiperiphery of the World System: the Portuguese Case).

Santos, A. C., Serra, N. and Teles, N. (2015) 'Finance and housing provision in Portugal', Fessud Working Paper n ${ }^{\circ}$ 79; Leeds: FESSUD project, available at: http://fessud.eu/wp-content/uploads/2015/01/FESSUD_Working-PaperSeries_Santos-Serra-Teles-2015-79.pdf

Stockhammer, E. (2004) 'Financialisation and the slowdown of accumulation', Cambridge Journal of Economics 28: 719-41.

Sweezy, P. (1994) 'The triumph of financial capital', Monthly Review 46(2): 1-11.

Teles, N. (2015) 'Financialisation and neoliberalism: the case of water provision in Portugal', Fessud Working paper, n 102; Leeds: FESSUD project, available at: http:/ / fessud.eu/wp-content/uploads/2015/03/Financialisation-and-neolib eralism-the-case-of-water-provision-in-Portugal-working-paper-102.pdf

Van Treeck, T. (2009) 'The political economy debate on 'financialisation' - a macroeconomic perspective', Review of International Political Economy 16(5): 907-44.

Wallerstein, I. (1974) Semi-Peripheral Countries and The Contemporary World Crisis. New York City: Academic Press.

Zhang, X. (2009) 'From banks to markets: Malaysian and Taiwanese finance in transition', Review of International Political Economy 16(3): 382-408. 